\title{
The first record of a julid millipede (Diplopoda: Julida: Julidae) from the Altai Mountains of Mongolia
}

\author{
P.S. Nefediev ${ }^{1}$, Ju.S. Nefedieva ${ }^{2}$, K. Jankowski ${ }^{3}$ \\ ${ }^{1}$ Altai State University, Lenina Av.,61, Barnaul656049 Russia.E-mail: p.nefediev@mail.ru \\ 2 Barnaul Branch of OJSC "GIPRODORNII”, Papanintsev Str., 105, Barnaul 656000 Russia. \\ ${ }^{3}$ Siedlce University of Natural Sciences and Humanities, Konarskiego Str. 2, 08-110 Siedlce, Poland.
}

ABSTRACT. The present work puts on record the genus Julus Linnaeus, 1758 and $J$. kazakhus Mikhaljova, 2013, as well as the family Julidae and the order Julida they belong to, as new to the millipede fauna of Mongolia.

How to cite this article: Nefediev P.S., Nefedieva J.S., Jankowski K. 2015. The first record of a julid millipede (Diplopoda: Julida: Julidae) from the Altai Mountains of Mongolia // Invertebratze Zoology. Vol.12. No.2. P.213-214. doi: 10.15298/invertzool.12.2.07

KEY WORDS: millipedes, Julus, kazakhus, new records, distribution, East Kazakhstan, Mongolia.

\section{Первая находка кивсяка (Diplopoda: Julida: Julidae) с Алтайских гор Монголии}

\author{
П.С. Нефедьев ${ }^{1}$, Ю.С. Нефедьева², К. Янковский \\ ${ }^{1}$ Алтайский государственный университет, просп. Ленина, 61, Барнаул 656049 Россия. \\ ${ }^{2}$ Барнаульское отделение «ГИПРОДОРНИИ», ул. Папанинцев, 105, Барнаул 656000 Россия. \\ РЕЗЮМЕ. Настоящая работа приводит и род Julus Linnaeus, 1758, и вид J. kazakhus \\ Mikhaljova, 2013, а также семейство Julidae и отряд Julida, к которым они принадле- \\ жат, в качестве новых для фауны диплопод Монголии. \\ Как цитировать эту статью: Nefediev P.S., Nefedieva J.S., Jankowski K. 2015. The first \\ record of a julid millipede (Diplopoda: Julida: Julidae) from the Altai Mountains of Mongolia \\ // Invertebratze Zoology. Vol.12. No.2. P.213-214. doi: 10.15298/invertzool.12.2.07
}

КЛЮЧЕВЫЕ СЛОВА: двупарноногие многоножки, Julus, kazakhus, новые находки, распространение, Восточный Казахстан, Монголия.

\section{Introduction}

The most recent review on millipede fauna of Mongolia (Mikhaljova, 2012) provides information about eight species from 4 genera, 2 families (Polyzoniidae and Diplomaragnidae) and 2 orders (Polyzoniida and Chordeumatida), also emphasizing the fauna as requiring further investigations. In the summer of 2015, a group of scientists from the Altai State University
(ASU), Barnaul, Russia collected new invertebrate material, including some Diplopoda, in the western part of Mongolia. The results of their efforts as regards millipedes form the basis of the present paper. It allows for a species, genus, family and order to be put on record as being new to the Mongolian list.

The material treated here was collected and kindly entrusted to us for study by A.A. Fomichev, an ASU post-graduate student. It is 


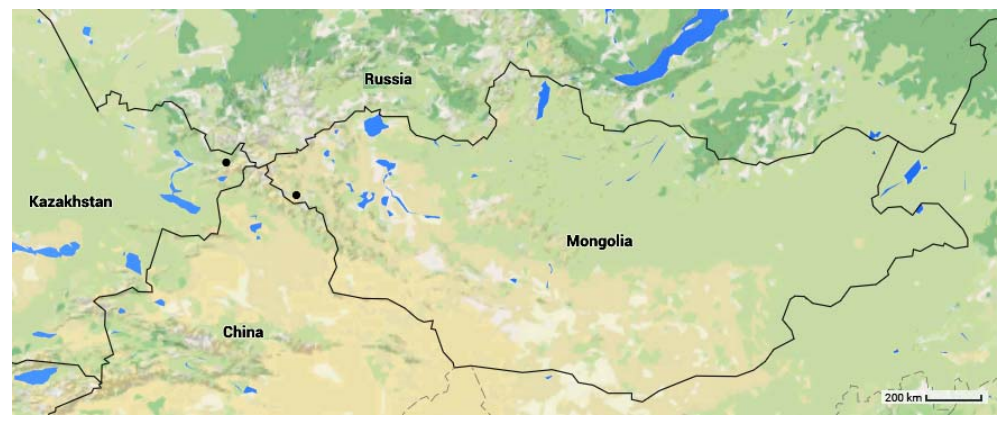

Map. Distribution of Julus kazakhus in Mongolia and Kazakhstan: filled circle - Julus kazakhus. Карта. Распространение Julus kazakhus в Монголии и Казахстане: круг — Julus kazakhus.

currently deposited in the ASU as indicated in the text.

\section{Taxonomic part}

\section{ORDER JULIDA Family JULIDAE}

Julus kazakhus Mikhaljova, in Mikhaljova, Ulykpan et Burkitbaeva, 2013 Map.

Julus kazakhus - Mikhaljova et al., 2013: 5, figs. MATERIAL EXAMINED. $20^{7} \sigma^{7}, 5$ 우, 4 juv. (ASU), Mongolia, Mongolian Altai, Bayan-Ölgii Province (Aimag), Altai District (Somon), Tsengel Hayrhan Nuruu Mt. Range, $5 \mathrm{~km} \mathrm{~W}$ of Mt. Elt Uul, $48^{\circ} 09^{\prime} \mathrm{N} ; 89^{\circ} 11^{\prime} \mathrm{E}$, small patches of scree in Juniperus thicket, 2500 m a.s.l., 11.07.2015, leg. A.A. Fomichev.

DISTRIBUTION. This julid millipede appears to be widespread in the south of the Altai Mountains within both East Kazakhstan (Mikhaljova et al., 2013) and western Mongolia. The above records are presently the eastern- and southernmost (Map), but the species may well prove to inhabit the Chinese Altai as well.

REMARKS. The above is the first formal report of this species in Mongolia where it dwells high in the mountains within a Juniperus thicket at $2500 \mathrm{~m}$ a.s.l. All previous records of $J$. kazakhus have come from East Kazakhstan, mainly from forested steppe habitats at 1200 $1470 \mathrm{~m}$ a.s.1. The new record of J. kazakhus in Mongolia also seems to be the highest elevation for the entire genus Julus Linnaeus, 1758.

\section{Conclusions}

The present record of Julus kazakhus Mikhaljova, 2013 in the Altai Mountains of western Mongolia allows to consider the genus Julus Linnaeus, 1758, as well as the family Julidae and the order Julida they belong to, are new to the millipede fauna of this country. The Mongolian locality of $J$. kazakhus considerably expands the range limit of the entire genus to the east and south.

To date, at least 9 species from 5 genera, 3 families and three orders ofDiplopoda are known to occur in Mongolia.

ACKNOWLEDGEMENTS. We are most grateful to R.V. Yakovlev (Barnaul, Russia) for the organization of the expedition to Mongolia, where A.A. Fomichev (Novosibirsk, Russia) also took part and collected the above sample. We are most thankful both to S.I. Golovatch (Moscow, Russia) and E.V. Mikhaljova (Vladivostok, Russia) who kindly edited advanced drafts of the paper.

\section{References}

Mikhaljova E.V. 2012. The class Diplopoda in Mongolia, with description of a new species // Zootaxa. No.3418. P.41-50.

Mikhaljova E.V., Ulykpan K., Burkitbaeva U.D. 2013. New data on the millipedes (Diplopoda) from East Kazakhstan (Altai) // Far Eastern Entomologist. No.260. P.1-11. 